\title{
ASSESSING THE VALIDITY AND RELIABILITY OF A QUESTIONNAIRE ON COOPERATION BETWEEN LEARNING PLACES (VOCATIONAL HIGH SCHOOL AND INDUSTRY)
}

\author{
Rita Fransina Maruanaya ${ }^{1}$ and Thomas Köhler ${ }^{2}$ \\ ${ }^{1}$ Institute of Vocational Education and Vocational Didactics, Faculty of Education, TU \\ Dresden, Germany \\ ${ }^{1}$ Department of German Language Education, Pattimura University, Indonesia \\ ${ }^{2}$ Institute of Vocational Education and Vocational Didactics, Faculty of Education, TU \\ Dresden, Germany \\ Corresponding Author: Rita Fransina Maruanaya \\ E-mail: rita_fransina.maruanaya@mailbox.tu-dresden.de
}

\begin{abstract}
This study aimed to measure the validity and reliability of the questionnaire in the context of scientific research on the cooperation of vocational high schools and industry for example in the field of Hotel management. Participants $(n=20)$ were teachers of Vocational High Schools and Trainers of Hotels. This is a quantitative study. The validity test was conducted through items content validity using Pearson Correlation Product Moment. The Cronbach Alpha value was applied to determine the reliability of the questionnaire. The result showed that questionnaire is valid with 35 questions and the values of Cronbach Alpha are Variable 1=0,94 (perfect), Variable 2=0,84 (high), Variable $3=0,53$ (average), Variable $4=0,92$ (perfect). Based on the results, it can be stated that the questionnaire is valid and reliable. Therefore, it can be used as an instrument for a study.
\end{abstract}

Keywords: Assessing, validity, reliability, cooperation, learning places.

\section{INTRODUCTION}

The collaboration between Vocational High Schools and Industry in Indonesia or the concept of link and match was introduced by Prof. Dr. Ing. Wardiman Djojonegoro while serving as Minister of Education and Culture, which concept refers to the link and match between the world of education and the world of industry (Djojonegoro 2007, p. 1). The purpose of link and match is that the competence of graduates from the education world can be accepted and match the needs of the world of work. The link perspective shows the process, which means that the educational process should match the needs of development, so that the results match these needs, both in terms of quantity, quality, type, qualification and in terms of time. Some of the principles that will be used in the strategy in the link and match policy include the implementation model of Dual System Education which is adapted from the German dual system vocational education system.

Vocational high schools, which are expected to be a link and match bridge because they have a dual education system, have not met expectations either. There are still many Vocational high schools graduates who have not been absorbed by the world of work. Based on data from the Central Statistics Agency in 2019, the unemployment rate in Indonesia reached 7.05 million people, where Vocational high schools graduates occupied the top position, it was $10.42 \%$. The non-absorption of Vocational high school graduates is not absolute due to the absence of job opportunities, but because of the low competency of graduates. Many job vacancies available have not been filled because applicants do not meet employer criteria. Many are found among graduates who work, not in accordance with their competency areas. Some companies that still care about and take advantage of Vocational high school graduates place these graduates to work in posts that are not in accordance with their majors.

Received December $15^{\text {th }} 2020$, Revision January $24^{\text {th }} 2021$, Accepted for publication February $24^{\text {th }} 2021$.

Copyright (C) 2021 Published by FKIP - Unpatti, ISSN 2721-3110 
The problem of unemployment should not necessarily occur in Vocational High School graduates, because vocational high schools emphasize the preparation of students to enter the world of work completed with the skills obtained from the practical learning process. The learning process at Vocational High School allows students to gain knowledge at school and carry out Industrial Work Practices.The purpose of internship is very important because students get direct experience in the world of work. The main target of internship is to optimize learning outcomes and produce graduates who have professional skills and are in accordance with the demands of the job market (Gröner \& Brüninghoff 2004, p. 136).

According to Muliati (2007, p. 32) the lack of quality of Vocational High School graduates is caused by various factors, such as less qualified teachers and trainers, a curriculum that is not in accordance with the needs of the labor market, lack of opportunities for students to practice, lack of offers for seminars, workshops and education, as well as other training and lack of quality job training in companies. Furthermore, Muliati said that the problems mentioned above could be resolved by optimizing the cooperation between the central government, including Ministry of Education, Ministry of Manpower, Business and Industry, Work Organization Institutions, Teachers and Trainers. With good cooperation, the quality of vocational education in Indonesia can be improved. In relation to this, Tsimoschanka (2013, p.116) mentioned that the cooperative approach is an approach to bring together vocational training institutions and the world of business and industry or to link theory and practice in job training. The term cooperation between learning places can thus be understood broadly as organized and carried out cooperation between vocational training providers and Industry with the aim of practically training trainees in a labor market orientation. Pahl (2014, p. ) further stated that Cooperation between learning places is a form of implementing education and vocational skills training that combines systematically and synchronously between educational programs in schools and work mastery programs, which aims to produce a workforce with professional expertise, improve and strengthen links and matches between educational institutions. vocational training and the world of work, increasing the efficiency of the education process and training for quality and professional workers, and recognizing and rewarding work experience as part of the educational process. Partnership between educational institutions and the business/industry world is the key to the success of Dual System Education in Vocational Schools, where education is designed, implemented and evaluated together, so that the relevance of graduate competencies to the demands of the job market increases. According to the Swiss Vocational Education Law 2002 in Euler (2003, p. ), cooperation between learning places is a collaboration between vocational and companies. Apart from cooperation with companies, vocational schools also collaborate with related associations such as training associations and courses, both private and public. The training associations and courses consist of several companies that offer intensive professional training to training participants.

Cooperation between vocational schools and industry can occur at three levels (Buschfeld \& Euler in Köhler \& Neumann 2013, p. ), including:

- At the communication level, teachers and trainers can exchange information; they inform each other about their hopes, experiences and problems in daily training. Information means two things by providing information and receiving information.

- At the coordination level, teachers and trainers agree on and develop stages which they carry out collaboratively and on their own responsibility under their respective institutional frameworks.

- At the cooperative level, teachers and trainers pursue joint projects in the context of direct cooperation.

Received December $15^{\text {th }} 2020$, Revision January $24^{\text {th }} 2021$, Accepted for publication February $24^{\text {th }} 2021$.

Copyright (C) 2021 Published by FKIP - Unpatti, ISSN 2721-3110 
Every problem requires a solution which surely can be achieved in various ways. Scientifically, a research is needed that aims to gain knowledge about a symptom, so that it can formulate problems appropriately, formulate and test hypotheses, describe completely the characteristics of situation, individual and group behaviour, get information about the frequency of event and obtain data regarding the relationship between one symptom and another. Research on the collaboration between Vocational High School and Industry has indeed been frequently carried out but the research instrument in the form of a questionnaire is still very rare. To get complete data about the cooperation activities between Vocational High School and Industry, it is necessary to conduct a survey. In survey research, the use of a questionnaire is the main thing in data collection. According to Mayer $(2008$, p.58) a questionnaire is a data collection tool to obtain information by sending or providing a written list of questions to respondents or people who receive a list of questions to fill out. The main objective of making a questionnaire is to obtain information relevant to the objectives of the survey and information with a high level of reliability and validity.

According to Pujihastuti (2010), the steps to develop a questionnaire are:

1. Determining the purpose of the questionnaire. In this case, it is necessary to know what data or information you want to collect from the questionnaire and what is the main purpose of the research to be carried out

2. Defining a research question. A research question is one or more questions that are the main focus of the questionnaire.

3. Developing one or more hypotheses to be tested. The questions in the questionnaire must be directed in such a way as to test the validity of the hypothesis.

4. Making an instrument grid that contains the concepts outlined in the variables which are indicators tailored to the research objectives. Each indicator is then used as a guide in compiling the questionnaire.

5. Selecting the question type. There are several types of questions that are commonly used in research questionnaires; Each type has its own advantages and disadvantages, and it really depends on the data or information you want to collect. Several types of questions are commonly used in questionnaires:

a. Dichotomous questions: dichotomous questions can only be answered with "yes" or "no"; sometimes, there are also questionnaires that provide "agree" or "disagree" answers. This type of question is easiest to analyze, but it cannot be used as an accurate and detailed measurement tool.

b. Open-ended questions: open-ended questions allow the respondent to elaborate on answers. In general, this type of question is useful for understanding the respondent's point of view, but it is very difficult to analyze. This type of question should be used to answer the "why" question.

c. Multiple choice questions: this type of question is completed with three or more conflicting answers; the respondent is then asked to choose one or more answers that he thinks are the most appropriate. Multiple choice questions can be analyzed easily, but they may not involve the answer the respondent wants most.

Received December $15^{\text {th }} 2020$, Revision January $24^{\text {th }} 2021$, Accepted for publication February $24^{\text {th }} 2021$.

Copyright (C) 2021 Published by FKIP - Unpatti, ISSN 2721-3110 
d. Questions in the form of an ordinal scale/rating scale: This type of question asks the respondent to sort the answer choices provided. For example, the respondent may be asked to rank five answer choices starting from least important to most important. This type of questioning indirectly forces the respondent to discriminate against the existing choices, but is unable to explain the reasons behind the choice of the respondent.

e. Multilevel scale questions: this type of question allows the respondent to rate an issue based on the available measurement scale. You can provide a measuring scale in the form of numbers 1-5; Number 1 represents the answer "strongly disagree", while number 5 represents the answer "strongly agree". This type of question is very flexible, but unable to answer the question "why".

6. Testing the questionnaire. Before the actual use in research, it is necessary to test the content and editorial language of the completed questionnaire. The objectives of this trial were as follows: a) To avoid questions that were unclear. b) To eliminate the use of words that are too foreign, too academic, or words that raise suspicion. c) To correct questions that are usually skipped or only generate superficial answers. d) To add items that are very necessary or eliminate items that are not relevant to the research objectives. e) Through this try out the questionnaire is also tested for validity and reliability. A good instrument has high validity and reliability.

7. Revision of the questionnaire. The results of the questionnaire trial were used as the basis for revising the questionnaire. Revision of the questionnaire was carried out by eliminating invalid question items as long as there were representative items.

Mummendey \& Grau (2014. p. 13) defined A questionnaire as a list of written questions addressed to respondents. The questionnaire is an efficient data collection method if the researcher knows exactly what data or information is needed and how the variables that state the information needed are measured. The questions posed in the questionnaire must be clear and easy to understand to reduce the respondent's misinterpretation in filling out the questionnaire. Information on the results of the questionnaire will be manifested in figures, tables, statistical analysis, descriptions and conclusions from the research results. The accuracy of testing a hypothesis about the relationship between research variables is dependent on the quality of the questionnaire used. This research hypothesis testing will not hit the target if the questionnaire used is invalid and reliable. Therefore, in order for research results to be scientifically accountable, information concerning the validity and reliability of measuring instruments must be conveyed in detail. According to Mayer (2008, p. 56), the validity test is used to test the accuracy or accuracy of an instrument as a measuring tool for research variables. If the measuring instrument is valid or correct, the measurement results will certainly be correct, or in other words, validity talks about how a measuring instrument used has indeed measured what it wants to measure. If the measuring instrument used by researchers is a questionnaire in data collection, the questionnaire that is compiled must describe the topic to be studied. One measure of the validity of a questionnaire is what is known as construct validity. In this understanding, a questionnaire containing several questions to measure something is said to be valid if each item of the question that makes up the questionnaire has a high correlation. The size of the relationship

Received December $15^{\text {th }} 2020$, Revision January $24^{\text {th }} 2021$, Accepted for publication February $24^{\text {th }} 2021$.

Copyright (C) 2021 Published by FKIP - Unpatti, ISSN 2721-3110 
between these question items is generally reflected by the correlation between the answers between the questions. Questions that have low correlation with other question items are declared as invalid questions. The method that is often used to assess the validity of the questionnaire is the moment product correlation (Pearson correlation) between the scores of each question item and the total score, so it is often referred to as the inter item total correlation (Siyoto \& Sodik, 2005. p. 88). While the reliability test is a test that is oriented to the degree of stability, consistency, predictive power, and accuracy. This test is carried out to see the suitability of the value of a questionnaire carried out by a respondent at different occasions or times and with the same questionnaire. Reliability comes from the word Rely, which means trust and reliable, which means trustworthy. Trustworthiness is all about accuracy and consistency. A learning outcome test is said to be reliable if it provides consistent measurement of learning outcomes (Siyoto \& Sodik, 2005. P. 91).

Kerlinger in (Siyoto \& Sodik, 2005. P. 91) provides limitations regarding reliability, including: 1) Reliability is achieved when we measure the same set of objects repeatedly with the same or similar instruments will give the same or similar results. 2) Reliability is achieved when the measure obtained from a measuring instrument is a "true" measure for the properties being measured. 3) Reliability is achieved by minimizing the measurement errors found in a measuring instrument. According to Azwar (2012), reliability is related to the accuracy of the instrument in measuring what is measured, the accuracy of the measurement results and how accurate it is if repeated measurements are made. Azwar also stated that reliability is the consistency of observations obtained from repeated notes on both one subject and a number of subjects.

So, from the various definitions of reliability, it can be concluded that reliability is related to the ability of the measuring instrument to make measurements carefully. Reliability is the accuracy and precision produced by measuring instruments in making measurements. The reliability of a measurement also shows the extent to which the measurement was carried out properly or free from errors, thus providing assurance that the measurement result data is consistent even at different times. In practice, reliability is not always tested by retesting (test retest), but there is also another technique called internal consistency approach which allows researchers to test the reliability of the questionnaire with only one measurement. This approach is used based on economic, time and cost considerations. Thus, based on the above discussion, this research will test the validity and reliability of the questionnaire regarding Vocational High School Cooperation and Industry, especially hotels.

\section{METHODOLOGY}

\section{Research methods}

This research used quantitative methods, it was research that emphasized objective phenomena and was studied quantitatively. According to Sukmadinata (2009), the maximization of the objectivity of quantitative research designs was carried out by using numbers, statistical processing, structure and controlled experiments.

\section{Research Subjects and Locations}

Subjects or participants in this research were vocational teachers who taught hospitality expertise and hospitality instructors. The sampling technique used in this study was purposive sampling, which was a non-probability sampling technique, where each element in the population did not have the same opportunity or opportunity to be selected as a

Received December $15^{\text {th }} 2020$, Revision January $24^{\text {th }} 2021$, Accepted for publication February $24^{\text {th }} 2021$.

Copyright (C) 2021 Published by FKIP - Unpatti, ISSN 2721-3110 
sample. The sample selection selected by the researcher was based on the special characteristics of the sample which are considered to be closely related to the characteristics of the previously known population. Respondents in this study consisted of 3 vocational school teachers and 4 hotel instructors in Maluku Province, 3 vocational school teachers and 4 hotel instructors in Papua Province, 3 vocational teachers and 3 hotel instructors in North Sulawesi Province. Thus the number of samples was 20 people.

\section{Data collection technique}

To collect data, an instrument in the form of a questionnaire was used consisting of 30 closed questions. In measuring the data, a Likert scale was used with 4 options, including strongly agree $=$ score 4 , agree $=$ score 3 , disagree $=$ score 2 , strongly disagree $=$ score 1 . The questionnaire was sent to each respondent via email to be filled in and then the results were sent to the researcher also by email. After the data was collected, validity and reliability tests were carried out.

Validity testing was carried out using the Pearson Correlation Product Moment formula between the scores of each questionnaire item and the total score (Siyoto \& Sodik, 2005. p. 88) using the SPSS statistical program. The instrument was said to be valid if the correlation value (pearson correlation) was positive, and the correlation probability value $(2$-tailed) $<$ significant level $(\alpha)$ was 0.05 .

$$
r_{x y}=\frac{N \cdot \sum \mathrm{x} \cdot y-\left(\sum X\right)\left(\sum Y\right)}{\sqrt{\left[N \cdot \sum X^{2}-\left(\sum X\right)^{2}\right]\left[N \cdot \sum Y^{2}-\left(\sum Y\right)^{2}\right]}}
$$

- rxy: Correlation of item score and item total score

- $\mathrm{n}$ : Number of respondents

- $\mathrm{x}$ : Score per item in variable

- y: Total score of items in variable

- $\quad \sum \mathrm{x}$ : Total score in distribution

- $\quad \sum y: \quad$ Total score in distribution

The method used to measure the reliability of the questionnaire was the Cronbach 's Alpha method (Sekaran, 2000, p.321) using the R-Studio Program-psych package. The Criteria, that is used to determine the reliability of the variables according to Sekaran $(2000$, p. 321) is $>0,90=$ Perfect, $0,70-0,90=$ High, $0,50-0,70=$ Average, and $<0,50$ unacceptable.

$$
r_{11}=\left(\frac{n}{n-1}\right)\left(1-\frac{\sum \sigma_{t}^{2}}{\sigma_{t}^{2}}\right)
$$

- $\mathrm{r} 11=$ reliability coefficient alpha

- $\mathrm{n} \quad=$ number of respondents

- $\sigma \quad=$ variance value

- $\mathrm{t} \square=$ total variance

Received December $15^{\text {th }} 2020$, Revision January $24^{\text {th }} 2021$, Accepted for publication February $24^{\text {th }} 2021$. Copyright (C) 2021 Published by FKIP - Unpatti, ISSN 2721-3110 


\section{Result and Discussion}

\subsection{Questionnaire}

Table 1. Variable 1: Industry's Participation in Organizing Vocational Education

\begin{tabular}{|c|c|c|c|c|c|}
\hline \multirow[b]{2}{*}{ Item } & \multirow[b]{2}{*}{ Question } & \multicolumn{4}{|c|}{ Answer } \\
\hline & & $\begin{array}{c}\text { Strongly } \\
\text { Agree }\end{array}$ & Agree & Disagree & $\begin{array}{l}\text { Strongly } \\
\text { Disagree }\end{array}$ \\
\hline 1 & $\begin{array}{l}\text { Hotel experts play an active role in } \\
\text { formulating } \\
\text { standards }\end{array}$ & & & & \\
\hline 2 & $\begin{array}{l}\text { Hotel experts take an active role together } \\
\text { with schools and school committees in } \\
\text { determining school policies and programs }\end{array}$ & & & & \\
\hline 3 & $\begin{array}{l}\text { Hotel experts have an active role together } \\
\text { with schools and school committees in } \\
\text { determining the criteria for educational } \\
\text { facilities in schools }\end{array}$ & & & & \\
\hline 4 & $\begin{array}{l}\text { Hotel experts also play an active role } \\
\text { together with schools and school } \\
\text { committees in determining the criteria for } \\
\text { school collaboration with DUDI and the } \\
\text { community }\end{array}$ & & & & \\
\hline 5 & $\begin{array}{l}\text { Hotel experts also play an active role in } \\
\text { analysing the needs of the labour market }\end{array}$ & & & & \\
\hline 6 & $\begin{array}{l}\text { Hotel experts also play an active role in } \\
\text { determining subjects in the field of tourism } \\
\text { expertise }\end{array}$ & & & & \\
\hline 7 & $\begin{array}{l}\text { Hotel experts also play an active role in } \\
\text { developing Teaching Plans }\end{array}$ & & & & \\
\hline 8 & $\begin{array}{l}\text { Hotel experts also play an active role in } \\
\text { formulating learning materials }\end{array}$ & & & & \\
\hline 9 & $\begin{array}{l}\text { Hotel experts also play an active role in } \\
\text { formulating learning objectives }\end{array}$ & & & & \\
\hline 10 & $\begin{array}{l}\text { Hotel experts also play an active role in } \\
\text { determining learning methods }\end{array}$ & & & & \\
\hline 11 & $\begin{array}{l}\text { Hotel experts also play an active role in } \\
\text { determining learning media }\end{array}$ & & & & \\
\hline 12 & $\begin{array}{l}\text { Hotel experts take an active role in } \\
\text { determining the distribution of material } \\
\text { and time for theory and practice both in } \\
\text { schools and in hotels }\end{array}$ & & & & \\
\hline 13 & $\begin{array}{l}\text { Hotel experts together with the school, } \\
\text { especially the subject teachers determine } \\
\text { the standard assessment theory test }\end{array}$ & & & & \\
\hline
\end{tabular}

Received December $15^{\text {th }} 2020$, Revision January $24^{\text {th }} 2021$, Accepted for publication February $24^{\text {th }} 2021$.

Copyright (C) 2021 Published by FKIP - Unpatti, ISSN 2721-3110 
14 Hotel experts together with the school, especially subject teachers, determine the standard of practical test assessment

Table 2. Variable 2: Industry's Participation in the Implementation of Vocational Education

\begin{tabular}{|c|c|c|c|c|c|}
\hline \multirow[b]{2}{*}{ Item } & \multirow[b]{2}{*}{ Question } & \multicolumn{4}{|c|}{ Answer } \\
\hline & & $\begin{array}{c}\text { Strongly } \\
\text { Agree }\end{array}$ & Agree & Disagree & $\begin{array}{l}\text { Strongly } \\
\text { Disagree }\end{array}$ \\
\hline 15 & $\begin{array}{l}\text { Hotels and schools sign an agreement on } \\
\text { cooperation in implementing regular } \\
\text { practice for vocational students in hotels }\end{array}$ & & & & \\
\hline 16 & $\begin{array}{l}\text { Vocational high school students practice } \\
\text { more in hotels than learning theory at } \\
\text { school }\end{array}$ & & & & \\
\hline 17 & $\begin{array}{l}\text { Hotel experts prepare a Program Design or } \\
\text { Job Training module for apprentices } \\
\text { together with teachers of related subjects }\end{array}$ & & & & \\
\hline 18 & $\begin{array}{l}\text { Hotel experts together with subject } \\
\text { teachers prepare test questions or } \\
\text { competency tests for vocational students }\end{array}$ & & & & \\
\hline 19 & $\begin{array}{l}\text { Hotel staff together with subject teachers } \\
\text { become examiners in the test or } \\
\text { competency test of vocational students in } \\
\text { schools }\end{array}$ & & & & \\
\hline 20 & $\begin{array}{l}\text { Hotel periodically conducts face to face } \\
\text { with schools, especially with students in an } \\
\text { effort to convey the latest information } \\
\text { about the world of Hospitality Work }\end{array}$ & & & & \\
\hline 21 & $\begin{array}{l}\text { Hotel also utilizes Internet media } \\
\text { (websites, video conferencing, email, } \\
\text { Facebook and Skype) to convey the latest } \\
\text { information to schools }\end{array}$ & & & & \\
\hline 22 & $\begin{array}{l}\text { Hotel experts and teachers, regularly } \\
\text { exchange information about experiences, } \\
\text { expectations and problems faced in } \\
\text { relation to the implementation of daily job } \\
\text { training }\end{array}$ & & & & \\
\hline 23 & $\begin{array}{l}\text { Exchange of information between teachers } \\
\text { and hoteliers about experiences, } \\
\text { expectations and problems faced in } \\
\text { connection with the implementation of } \\
\text { daily job training is often done directly }\end{array}$ & & & & \\
\hline 24 & $\begin{array}{l}\text { Exchange of information between teachers } \\
\text { and hoteliers about experiences, }\end{array}$ & & & & \\
\hline
\end{tabular}

Received December $15^{\text {th }} 2020$, Revision January $24^{\text {th }} 2021$, Accepted for publication February $24^{\text {th }} 2021$. Copyright (C) 2021 Published by FKIP - Unpatti, ISSN 2721-3110 


\begin{tabular}{|l|l|l|l|l|}
\hline & $\begin{array}{l}\text { expectations and problems faced in } \\
\text { relation to the implementation of daily job } \\
\text { training also utilizing digital media }\end{array}$ & $\begin{array}{l}\text { Hotel Experts together with schools, } \\
\text { especially school leaders and teachers, } \\
\text { always try to find solutions if there are } \\
\text { problems in the process of implementing } \\
\text { job training }\end{array}$ & & \\
\hline
\end{tabular}

Table 3. Variable 3: Industry's participation in the form of financial support

\begin{tabular}{|c|l|c|c|c|c|}
\hline \multirow{2}{*}{ Item } & \multicolumn{1}{|c|}{ Question } & \multicolumn{3}{|c|}{ Answer } \\
\cline { 3 - 6 } & $\begin{array}{l}\text { Strongly } \\
\text { Agree }\end{array}$ & Agree & Disagree & $\begin{array}{l}\text { Strongly } \\
\text { Disagree }\end{array}$ \\
\hline 26 & $\begin{array}{l}\text { Hotel provides financial assistance in the } \\
\text { context of providing teaching and learning } \\
\text { facilities at schools }\end{array}$ & & & \\
\hline 27 & $\begin{array}{l}\text { Hotel provides salaries for students who } \\
\text { practice in hotels }\end{array}$ & & & & \\
\hline 28 & $\begin{array}{l}\text { Hotel provides financial assistance for } \\
\text { vocational school teachers who attend } \\
\text { training. }\end{array}$ & & & \\
\hline 29 & $\begin{array}{l}\text { Hotel provides scholarships for high- } \\
\text { achieving vocational students }\end{array}$ & & & & \\
\hline
\end{tabular}

Table 4. Variable 4: Industry`s participation in the form of organizational structure and personnel development

\begin{tabular}{|c|c|c|c|c|c|}
\hline \multirow[b]{2}{*}{ Item } & \multirow[b]{2}{*}{ Question } & \multicolumn{4}{|c|}{ Answer } \\
\hline & & $\begin{array}{c}\text { Strongly } \\
\text { Agree }\end{array}$ & Agree & Disagree & $\begin{array}{l}\text { Strongly } \\
\text { Disagree }\end{array}$ \\
\hline 30 & $\begin{array}{l}\text { Vocational High School and Hotel have } \\
\text { jointly formed an official Vocational } \\
\text { Education organizational structure at the } \\
\text { school level }\end{array}$ & & & & \\
\hline 31 & $\begin{array}{l}\text { This organizational structure simplifies the } \\
\text { process of communication and } \\
\text { coordination between hotels and schools }\end{array}$ & & & & \\
\hline 32 & $\begin{array}{l}\text { This organizational structure also clarifies } \\
\text { the division of duties of each party, both } \\
\text { schools and hotels }\end{array}$ & & & & \\
\hline 33 & $\begin{array}{l}\text { The formation of this organizational } \\
\text { structure is driven by the existence of a } \\
\text { collaborative relationship between } \\
\text { Vocational High School and Hotel }\end{array}$ & & & & \\
\hline
\end{tabular}

Received December $15^{\text {th }} 2020$, Revision January $24^{\text {th }} 2021$, Accepted for publication February $24^{\text {th }} 2021$.

Copyright (C) 2021 Published by FKIP - Unpatti, ISSN 2721-3110 


\begin{tabular}{|c|l|l|l|l|l|}
\hline 34 & $\begin{array}{l}\text { Hotel and schools signed an agreement on } \\
\text { cooperation in implementing competency } \\
\text { training for vocational teachers }\end{array}$ & & & & \\
\hline 35 & $\begin{array}{l}\text { Hotel regularly conducts training activities } \\
\text { to increase the capacity of Vocational High } \\
\text { School teachers }\end{array}$ & & & & \\
\hline
\end{tabular}

\subsection{Validity Test}

\section{Table 5. Result and Interpretation of Validity Test}

\begin{tabular}{|c|c|c|c|c|}
\hline Item & $\begin{array}{c}\text { Pearson Correlation } \\
\text { (r Count) }\end{array}$ & Criteria & r Table & Interpretation \\
\hline Item 1 & 0,807 & \multirow[t]{32}{*}{ r Count $\geq \mathbf{r}$ Table } & 0,444 & Valid \\
\hline Item 2 & 0,840 & & 0,444 & Valid \\
\hline Item 3 & 0,790 & & 0,444 & Valid \\
\hline Item 4 & 0,688 & & 0,444 & Valid \\
\hline Item 5 & 0,828 & & 0,444 & Valid \\
\hline Item 6 & 0,764 & & 0,444 & Valid \\
\hline Item 7 & 0,821 & & 0,444 & Valid \\
\hline Item 8 & 0,585 & & 0,444 & Valid \\
\hline Item 9 & 0,862 & & 0,444 & Valid \\
\hline Item 10 & 0,844 & & 0,444 & Valid \\
\hline Item 11 & 0,678 & & 0,444 & Valid \\
\hline Item 12 & 0,843 & & 0,444 & Valid \\
\hline Item 13 & 0,594 & & 0,444 & Valid \\
\hline Item 14 & 0,511 & & 0,444 & Valid \\
\hline Item 15 & 0,509 & & 0,444 & Valid \\
\hline Item 16 & 0,806 & & 0,444 & Valid \\
\hline Item 17 & 0,798 & & 0,444 & Valid \\
\hline Item 18 & 0,782 & & 0,444 & Valid \\
\hline Item 19 & 0,671 & & 0,444 & Valid \\
\hline Item 20 & 0,507 & & 0,444 & Valid \\
\hline Item 21 & 0,478 & & 0,444 & Valid \\
\hline Item 22 & 0,466 & & 0,444 & Valid \\
\hline Item 23 & 0,491 & & 0,444 & Valid \\
\hline Item 24 & 0,518 & & 0,444 & Valid \\
\hline Item 25 & 0,493 & & 0,444 & Valid \\
\hline Item 26 & 0,486 & & 0,444 & Valid \\
\hline Item 27 & 0,488 & & 0,444 & Valid \\
\hline Item 28 & 0,492 & & 0,444 & Valid \\
\hline Item 29 & 0,798 & & 0,444 & Valid \\
\hline Item 30 & 0,811 & & 0,444 & Valid \\
\hline Item 31 & 0,769 & & 0,444 & Valid \\
\hline Item 32 & 0,801 & & 0,444 & Valid \\
\hline
\end{tabular}

Received December $15^{\text {th }} 2020$, Revision January $24^{\text {th }} 2021$, Accepted for publication February $24^{\text {th }} 2021$.

Copyright (C) 2021 Published by FKIP - Unpatti, ISSN 2721-3110 


\begin{tabular}{|l|l|l|l|l|}
\hline Item 33 & 0,765 & \multirow{5}{*}{} & 0,444 & Valid \\
\hline Item 34 & 0,769 & 0,444 & Valid \\
\hline Item 35 & 0,769 & & 0,444 & Valid \\
\cline { 5 - 5 }
\end{tabular}

Based on the results of testing the validity of the questionnaire listed in table 5 above, it could be seen that all items, from numbers 1 to 35, are declared valid, because $r$ count for each item was greater than $r$ table.

\subsection{Reliability Test}

Table 6. Result and Interpretation of Reliability Test

\begin{tabular}{|c|c|c|c|}
\hline Variable & Cronbach's Alpha & Criteria & Interpretation \\
\hline $\begin{array}{c}\text { Variable } 1 \\
\text { (item 1-14) }\end{array}$ & 0,94 & \multirow{4}{*}{$\begin{array}{l}>0,90=\text { Perfect } \\
0,70-0,90=\text { High } \\
0,50-0,70=\text { Average } \\
<0,50=\text { Unacceptable }\end{array}$} & perfect \\
\hline $\begin{array}{c}\text { Variable } 2 \\
\text { (item } 15-25 \text { ) }\end{array}$ & 0,84 & & high \\
\hline $\begin{array}{c}\text { Variable } 3 \\
\text { Item 26-29) }\end{array}$ & 0,53 & & average \\
\hline $\begin{array}{c}\text { Variable } 4 \\
\text { (Item 30-35) }\end{array}$ & 0,92 & & perfect \\
\hline
\end{tabular}

Based on the data in table 6, it was known that the four variables are reliable, where for variable 1 the reliability level was perfect because the Cronbach's alpha value was more than 0.90 , variable 2 the reliability level was high because the Cronbach's alpha value was between $0.70-0.90$, variable 3 was average because the Cronbach's alpha value was between 0.50-0.70 and variable 4 was perfect because the Cronbach's alpha value was more than 0.90 .

\section{Conclusion and Suggestion}

The questionnaire used in this research was valid and reliable, or in other words, the results of this questionnaire were really accurate and could be trusted to measure research variables on Vocational High School and Industrial Cooperation. However, it was still necessary to do further studies regarding the validity and reliability test, both retest reliability test, parallel form reliability test, and internal consistency reliability test with a larger number of samples. 
Edu Sciences J. Vol. 2, No. 1. March 2021, 17-28

\section{REFERENCES}

Azwar, S. (2012). Reliabilitas dan Validitas, Edisi 4, Pustaka Pelajar Yogyakarta

Djojonegoro, W. (1999). Pengembangan Sumber Daya Manusia: Melalui Sekolah Menengah Kejuruan (SMK), PT Balai Pustaka Jakarta

Euler, D. (2003). Handbuch der Lernortkooperation. Band 1: Theoretische Fundierungen. Bertelsmann Bielefeld

GRÖNER, H and BRÜNINGHOFF, E.F. (2004). Lexikon der Berufsausbildung. Über 1500 Begriffe für Ausbilder, Führungskräfte und Personalentwickler, Deutscher Taschenbuch Verlag München

Köhler, T. and Neumann, J. (2013) Das Online-Berichtsheft: Stärkung der Lernortkooperation in der dualen Berufsausbildung durch Web2. 0. W. Bertelsmann Verlag Bielefeld

Mayer, H.O. (2008) Interview und schriftliche Befragung - Entwicklung Durchführung Auswertung, Oldenburg Verlag München

MULIATI, A. (2007) Evaluasi program Pendidikan Sistem Ganda Suatu Penelitian Evaluatif Berdasarkan Stake Countenance Model Mengenai Program Pendidikan Sistem Ganda Pada Sebuah SMK, Sulawesi Selatan

Mummendey, H.D. und Grau, I. (2014). Die Fragebogen Methode-Grundlagen und Anwendung in Persönlichkeits-, Einstellungs- und Selbstkonzeptforschung, Hogrefe Verlag Göttingen

Pahl J.P. (2014). Berufsschule: Annäherungen an eine Theorie des Lernortes 3. wbv

Pujihastuti, I. (2010) Prinsip Penulisan Kuesioner Penelitiani Cefars. Jurnal Agribisnis dan Pengembangan Wilayah Vol. 2 No. 1 Desember

Tsimoshchanka, Y. (2014) Kooperative Berufsausbildung- Untersuchungen zum kooperativen Ansatz in der deutschen bilateralen Entwicklungszusammenarbeit in Zentralasien am Beispiel von Usbekistan und Kasachstan. Verlag Dr. Kovac Hamburg

Dixon, W.M., Agarwal, S., Young, B., Jones, D. \& Sutton A. (2004) Integrative Approaches to Qualitative and Quantitative Evidence. Health Development Agency London

Siyoto, S. and Sodik, A. M. (2015) Dasar Metodologi Penelitian Literasi Media Publishing Yogyakarta

Sukmadinata, N.S. (2009). Metode Penelitian Pendidikan. Rosda Karya Bandung

Received December $15^{\text {th }} 2020$, Revision January $24^{\text {th }} 2021$, Accepted for publication February $24^{\text {th }} 2021$.

Copyright (C) 2021 Published by FKIP - Unpatti, ISSN 2721-3110 